\title{
Scales for assessment of patients with traumatic brain injury
}

This article was published in the following Dove Press journal:

Patient Preference and Adherence

13 November 2015

Number of times this article has been viewed

Rita de Cassia Almeida

Vieira'

Daniel Vieira de Oliveira ${ }^{2}$

Manoel Jacobsen Teixeira ${ }^{2}$ Wellingson da Silva Paiva ${ }^{2}$

'Nursing School, ${ }^{2}$ Division of Neurological Surgery, University of Sao Paulo, Sao Paulo, Brazil
Correspondence: Rita de Cassia Almeida Vieira

478 Itapiru Street Apartment 93,

Sao Paulo 04I430 I0, Brazil

Tel +55 I। 269। I842

Fax +55 II 25486906

Email ritinhacav@yahoo.com.br

\section{Dear editor}

We read with great interest the paper by Ślusarz et $\mathrm{al}^{1}$ published in the Patient Preference and Adherence. The functional recovery after traumatic brain injury (TBI) is related to the severity of the brain lesion and the time after TBI. The consequences of brain damage remain beyond the acute phase, extending and modifying for a long period after the traumatic event. ${ }^{2}$ Knowing the functional recovery after TBI is relevant to evaluating the results of new techniques and treatments to minimize the severity of the disability. As a result, the pathophysiology of disability after TBI and the mechanisms involved in functional recovery are the subject of investigations, which provide the foundation to direct rehabilitation programs and guide the development of individualized therapy after TBI. ${ }^{3}$ Ślusarz et al's ${ }^{1}$ article focused on the role of establishing the relationships between measurements by the Glasgow Coma Scale (GCS) and the scales used for the assessment of functional capacity of TBI patients.

Although some studies have described the recovery of patients of TBI after trauma, there are few studies that evaluate the different aspects of functional capacity in the acute phase after brain injury and factors related to outcome. We agree with Ślusarz et $\mathrm{al}^{1}$ that studying the functional capacity and assessing the activities of daily living in patients with TBI facilitate the planning of systematic assistance, implementation of neurological rehabilitation, reintegration of patients in society, and a better warranted quality of life. A strength of the study is to analyze the functional capacity assessed by different scales at admission and at discharge, highlighting the correlation of recovery in both periods with the level of awareness, and the comparison of different scales that assess functional capacity and activities of daily life.

Our group has great interest in the assessment of functional recovery of TBI patients analyzed by different scales, in particular, patients with severe diffuse axonal injury (DAI) ${ }^{3,4}$ As discussed by Ślusarz et al, ${ }^{1}$ the evaluation of consciousness is a widely used prognostic parameter in the acute phase of trauma and identifies early the outcome of patients with severe TBI, and it is relevant in the face of the impairment of brain functions caused after TBI and the mechanisms involved in the recovery process. Clinical observations of TBI patients have suggested improvement during the first year, particularly during the first 6 months, with stabilizing of the recovery process thereafter. ${ }^{2,5-7}$ Research to assess the consequences for TBI patients showed that there is an improvement in functionality after trauma; however, how to measure functional recovery after TBI is still a challenge. Analysis of patients with severe TBI showed that advanced age and prolonged hospitalization were independent predictors of poor outcome after trauma. ${ }^{6}$ The lowest score of the Glasgow Coma Scale on admission is 
a factor associated with dependence or death of TBI patients, assessed 3 months after the trauma. ${ }^{7}$

Our research ${ }^{8}$ carried out with patients of DAI showed that severe DAI stood out as risk factor for mortality and dependence compared to focal injury. The length of hospitalization was identified as a risk factor related to dependence on outcome. In addition, other important scales can be used to assess functional recovery, mainly in severe trauma. We had used Katz scale and the Extended Glasgow Outcome Scale in patients with severe DAI, and we found similar results when assessing recovery at 6 months after DAI compared with results described by Ślusarz et al, ${ }^{1}$ using correlation results of the functional capacity scale and the functional index "Repty".

The results described by Ślusarz et $\mathrm{al}^{1}$ showed the importance of studying the recovery of patients with TBI after trauma since it identified greater independence of the patients after hospital discharge and a correlation between the level of awareness and functional capacity. The identification of functional recovery and its correlation with the outcome can guarantee the quality of care provided to patients and provide a better quality of life. However, we believe that functional recovery analysis of TBI patients is a complex issue, presents particularities, and maybe should be stratified according to severity of trauma, including the creation of appropriate scales for mild TBI, separated from moderate and severe TBI.

\section{Disclosure}

The authors report no conflicts of interest in this communication.

\section{References}

1. Ślusarz R, Jabłońska R, Królikowska A, et al. Measuring scales used for assessment of patients with traumatic brain injury: multicenter studies. Patient Prefer Adherence. 2015;9:869-875.

2. Sousa RMC, Koizumi MS. Recuperação das vítimas de traumatismo crânio-encefálico no período de 1 ano após o trauma. Rev Esc Enferm USP. 1996;30(3):484-500.

3. Zaninotto AL, de Paula Guirado VM, Baldivia B, et al. Improvement of verbal fluency in patients with diffuse brain injury over time. Neuropsychiatr Dis Treat. 2014;10:1155-1160.

4. Li S, Zaninotto AL, Neville IS, Paiva WS, Nunn D, Fregni F. Clinical utility of brain stimulation modalities following traumatic brain injury: current evidence. Neuropsychiatr Dis Treat. 2015;11:1573-1586.

5. Ham TE, Sharp DJ. How can investigation of network function inform rehabilitation after traumatic brain injury? Curr Opin Neurol. 2012; 25(6):662-669.

6. Taw BB, Lam AC, Ho FL, Hung KN, Lui WM, Leung GK. Functional survival after acute care for severe head injury at a designated trauma center in Hong Kong. Asian J Surg. 2012;35(3):117-122.

7. Wang HC, Wang PM, Lin YJ, et al. Serum adhesion molecules, outcome and neuro-psychological function in acute traumatic brain injury patients. Clin Chim Acta. 2013;423:122-129.

8. Vieira RCA. Outcome of diffuse Axonal Injury Victims and Associated Factors [thesis]. São Paulo: School of Nursing, University of Sao Paulo; 2015 . 


\section{Authors' reply}

Robert Ślusarz'

Renata Jabłońska'

Agnieszka Królikowska'

Beata Haor'

Ewa Barczykowska²

Monika Biercewicz ${ }^{3}$

Mariola Głowacka

Justyna Szrajda ${ }^{4}$

'Department of Neurological and Neurosurgical Nursing, ${ }^{2}$ Department of Nursing, ${ }^{3}$ Clinic of Geriatrics, ${ }^{4}$ Department of Hygiene and Epidemiology, Collegium Medicum, Nicolaus Copernicus University, Torun, Poland

Correspondence: Robert Ślusarz

Department of Neurological and Neurosurgical Nursing, Collegium

Medicum, Nicolaus Copernicus University, ul. Techników 3, 85-094

Bydgoszcz, Poland

Email zpielnin@cm.umk.pl

\section{Dear editor}

We would like to thank Rita de Cassia Almeida Vieira, Daniel Vieira de Oliveira, Manoel Jacobsen Teixeira, and Wellingson da Silva Paiva of Nursing School and Division of Neurological Surgery, University of Sao Paulo, Sao Paulo, Brazil, for showing interest in our publication and sharing their comment on usage of assessment scales in patients after traumatic brain injury. ${ }^{1}$

We are glad that this team of experienced researchers has decided to join the discussion on this topic especially that they are experts in nursing management of neurosurgical patients..$^{2-4}$

The comment is very valuable due to its merit and significant results of clinical and nursing practice. The authors' suggestion that the functional recovery analysis of patients with TBI should depend on the severity of injury (mild, moderate, and severe), which seems very interesting. We believe that this idea will be taken into consideration in the future on a bigger sample of patients. We will be happy to incorporate the experience of the Sao Paulo team into further studies.

\section{Disclosure}

The authors report no conflicts of interest in this communication.

\section{References}

1. Ślusarz R, Jabłońska R, Królikowska A, et al. Measuring scales used for assessment of patients with traumatic brain injury: multicenter studies. Patient Prefer Adherence. 2015;9:869-875.

2. Vieira Rde C, Hora EC, de Oliveira DV, Ribeiro Mdo C, de Sousa RM. Quality of life of victims of traumatic brain injury six months after the trauma. Rev Lat Am Enfermagem. 2013;21(4):868-875. doi:10.1590/ S0104-11692013000400006.

3. Vieira Rde C, Hora EC, de Oliveira DV, Vaez AC. An epidemiological survey on motorcycle accident victims assisted at a reference trauma center of Sergipe. Rev ESc Enferm USP. 2011;45(6):1359-1363.

4. Vieira RCA. Outcome of Diffuse Axonal Injury Victims and Associated Factors [thesis]. São Paulo: School of Nursing, University of Sao Paulo; 2015 .

Dove Medical Press encourages responsible, free and frank academic debate. The content of the Patient Preference and Adherence 'letters to the editor' section does not necessarily represent the views of Dove Medical Press, its officers, agents, employees, related entities or the Patient Preference and Adherence editors. While all reasonable steps have been taken to confirm the content of each letter, Dove Medical Press accepts no liability in respect of the content of any letter, nor is it responsible for the content and accuracy of any letter to the editor.

\section{Publish your work in this journal}

Patient Preference and Adherence is an international, peer-reviewed, open access journal that focuses on the growing importance of patient preference and adherence throughout the therapeutic continuum. Patient satisfaction, acceptability, quality of life, compliance, persistence and their role in developing new therapeutic modalities and compounds to optimize clinical outcomes for existing disease states are major areas of interest for the journal. This journal has been accepted for indexing on PubMed Central. The manuscript management system is completely online and includes a very quick and fair peer-review system, which is all easy to use. Visit http://www. dovepress.com/testimonials.php to read real quotes from published authors. 